\title{
Fossil-wood carbon-isotope stratigraphy of the non-marine Wealden Group (Lower Cretaceous, southern England)
}

\author{
STUART A. ROBINSON ${ }^{1,2} \&$ STEPHEN P. HESSELBO ${ }^{1}$ \\ ${ }^{1}$ Department of Earth Sciences, University of Oxford, Parks Road, Oxford OX1 3PR, UK \\ ${ }^{2}$ Present address: Lamont-Doherty Earth Observatory of Columbia University, 61 Route 9W, Palisades, NY 10964, USA \\ (e-mail: stuartr@ldeo.columbia.edu)
}

\begin{abstract}
Fossil-wood carbon-isotope data are presented for the Wessex Formation, a non-marine unit within the Lower Cretaceous (Valanginian-Barremian) Wealden Group of the Isle of Wight and Dorset, southern England. The carbon-isotope values have a range $\left(\delta^{13} \mathrm{C} c\right.$. -26.6 to $\left.-19.8 \%\right)$ that is consistent with that expected for Mesozoic $\mathrm{C}_{3}$ plants. Consideration of the Isle of Wight fossil-wood carbon-isotope data together with data from Dorset allows construction of a composite fossil-wood carbon-isotope curve for almost the entire Wealden Group. The new carbon-isotope curve is in smooth continuity with data previously published from the overlying lagoonal Vectis Formation and marine Lower Greensand Group of Aptian age. A tentative correlation with a Tethyan reference carbon-isotope curve allows the provisional application of stage-level chronostratigraphy to the Wealden Group. Correlations suggest that the Wealden Group sediments are dominantly of Hauterivian and Barremian age and that the Valanginian is either condensed or partially missing. The carbon-isotope data presented indicate that even during times of relative carbon-cycle quiescence atmosphere $\mathrm{CO}_{2}$ faithfully tracks the carbon-isotopic composition of the oceanic reservoir.
\end{abstract}

Keywords: Early Cretaceous, chemostratigraphy, carbon isotopes, fossil wood, Wealden Group.

Realization that major carbon-isotopic change in the oceans is also expressed by the isotopic composition of higher plant fossils leads to the potential use of terrestrial carbon-isotope stratigraphy as a means to link the non-marine and marine records of environmental change during times of significant disturbance to the carbon cycle (e.g. Hasegawa 1997; Gröcke et al. 1999; Hesselbo et al. 2000, 2002, 2003; Ando et al. 2002; Heimhofer et al. 2003). The Early Cretaceous (Berriasian-Barremian) carbon-isotope record is known from studies of Tethyan marine carbonates (e.g. Lini et al. 1992; Weissert et al. 1998) and it has been shown that there is a significant positive carbon-isotope event at about the Valanginian-Hauterivian boundary (Lini et al. 1992). The non-marine, fluvial Wealden Group of southern England contains fossil wood in local abundance and ranges in age from approximately the Berriasian-Valanginian to the Barremian, although the group lacks precise age constraints. In this paper we assess the utility of fossil-wood carbon-isotope stratigraphy in the intrabasinal correlation of the non-marine Wealden strata and the potential for extrabasinal correlation with the marine (standard) provided by Tethyan carbonates. The ability to correlate between a marine carbonate carbon-isotope curve and a fossil-wood carbon-isotope curve has important implications not only for stratigraphy but also for understanding the operation of the global carbon-cycle in the geological past and associated environmental changes on land.

\section{Rationale and geological background \\ $\delta^{13} C$ of fossil wood and application as a chemostratigraphic tool}

It is well known that in modern plants there is considerable variability in $\delta^{13} \mathrm{C}$ values within a single individual, between individuals of the same species and between different species of plants. Modern terrestrial plants can be divided into three groups on the basis of their photosynthetic pathway: $\mathrm{C}_{3}$ (Calvin-Benson cycle; includes temperate shrubs and trees), $\mathrm{C}_{4}$ (Hatch-Slack cycle; predominantly grasses), and $\mathrm{CAM}$ (crassulacean acid metabolism; mainly succulents). $\mathrm{C}_{3}$ and $\mathrm{C}_{4}$ plants can be distinguished by their characteristic carbon-isotopic values $\left(\mathrm{C}_{3}\right.$ plants: -23 to $-34 \%$; $\mathrm{C}_{4}$ plants: -8 to $-16 \%$; Bender 1971 ; Smith \& Epstein 1971; Vogel 1993). CAM plants, however, use an intermediate pathway that can be modified in response to changing environmental conditions and hence have intermediate carbon-isotope values. Therefore, the use of fossil plants for chemostratigraphy is dependent upon the assumption that the palaeo-ecosystem did not contain a mixture of plants utilizing more than one photosynthetic pathway. Fortunately for studies of the Cretaceous, evidence from the fossil record suggests that $\mathrm{C}_{4}$ plants did not evolve until the Miocene (Throughton et al. 1974; Cerling \& Quade 1993; Cerling et al. 1993) although, according to some isotopic evidence, they may have appeared sporadically during earlier geological time (see Spicer 1989; Wright \& Vanstone 1991; Kuypers et al. 1999). Mesozoic fossil plants generally have carbon-isotopic compositions consistent with a $\mathrm{C}_{3}$ photosynthetic pathway (Bocherens et al. 1993; Gröcke 1998).

Within modern $\mathrm{C}_{3}$ plants there is variability in the carbonisotopic composition of the constituent parts of the plant. Leaves are consistently lighter than the branches to which they are attached by as much as $3 \%$, and leaves themselves can vary by 4\%o on a single tree (Leavitt \& Long 1991; Schleser 1999). There is also considerable variation within twigs and branches (up to 2-3\%; Leavitt \& Long 1986; Schleser 1999) and between early and late wood (typically 1-2\%o; Leavitt \& Long 1982; Loader et al. 1995). To add further complication, the $\delta^{13} \mathrm{C}$ of plant material is affected by variations in temperature, salinity, water supply and local $p \mathrm{CO}_{2}$ (e.g. the canopy effect and altitude) (see Gröcke (1998) for a review). From a chemostratigraphic 
point of view analyses should clearly be restricted to consistent plant organs through a stratigraphic sequence, and only large reproducible patterns can be indicative of long-term shifts in atmospheric carbon-isotopic compositions.

The diagenetic and preservational history can affect the $\delta^{13} \mathrm{C}$ of preserved plant tissues. Carbohydrates are the chemical components least resistant to diagenesis and have $\delta^{13} \mathrm{C}$ values that are more positive than $\delta^{13} \mathrm{C}_{\text {plant }}$ whereas lignin and lipids are the most resistant to diagenesis and have ${ }^{13} \mathrm{C}$-depleted $\delta^{13} \mathrm{C}$ values compared with bulk plant (see Gröcke 1998). Spiker \& Hatcher (1987) indicated that fossil plants should have ${ }^{12} \mathrm{C}$-enriched carbon-isotopic compositions $(1-2 \%$ ) compared with the original (or modern) values because of the preferential loss of carbohydrates during diagenesis. Hence, most fossil $\mathrm{C}_{3}$ plants should have carbon-isotope compositions of -28 to $-29 \%$. However, most studies indicate that fossil coals and plants have $\delta^{13} \mathrm{C}$ values between -24 and $-25 \%$, indicating enrichment in ${ }^{13} \mathrm{C}$ relative to a modern average of $-27 \%$ (Gröcke 1998). The reason for this is not entirely clear but it may, in part, be due to ${ }^{13} \mathrm{C}$ enrichment during coalification and charcoalification (Colombo et al. 1968; Jones \& Chaloner 1991).

Scholle \& Arthur (1980, p. 83) were the first to suggest that carbon-isotope excursions discovered in marine carbonate "would be communicated through changes in the $\delta^{13} \mathrm{C}$ values of atmospheric $\mathrm{CO}_{2}$ to land plants'. During the last decade a number of studies have shown that despite the great variability in the carbon-isotopic composition of modern plants and potential postdepositional effects, it is possible to observe the same patterns through time in fossil wood as those patterns seen in marine carbonate and organic matter (e.g. Hasegawa 1997; Gröcke et al. 1999; Hesselbo et al. 2000, 2002, 2003; Ando et al. 2002; Beerling \& Royer 2002; Heimhofer et al. 2003), thereby confirming that the ocean-atmosphere carbon cycle was coupled during much of the Mesozoic.

\section{Early Cretaceous carbon-isotope stratigraphy}

The Early Cretaceous was a time of significant perturbations to the isotopic composition of both the shallow-oceanic and atmospheric carbon reservoirs. Strata of Aptian and younger age have been extensively studied, resulting in a now well-defined carbonisotope stratigraphy for this time period (e.g. Scholle \& Arthur 1980; Weissert \& Bréhéret 1991; Bralower et al. 1999; Jenkyns 1995; Menegatti et al. 1998; Weissert et al. 1998; Erba et al. 1999; Gröcke et al. 1999; Jenkyns \& Wilson 1999; Jahren et al. 2001; Luciani et al. 2001; Ando et al. 2002; Heimhofer et al. 2003).

However, the carbon-isotope stratigraphy of older Cretaceous sediments (Berriasian-Barremian) is less well studied. A significant positive carbon-isotope excursion occurs at about the Valanginian-Hauterivian boundary in both bulk carbonate and marine organic matter at several Tethyan and Atlantic localities (Lini et al. 1992; Föllmi et al. 1994; Michalík et al. 1995; Hennig et al. 1999; van de Schootbrugge et al. 2000; Wortmann $\&$ Weissert 2000). Hauterivian carbon-isotope records generally show a broad, long-term negative trough, which is followed by a broad positive excursion that spans the Barremian (e.g. Lini et al. 1992; Föllmi et al. 1994; Weissert et al. 1998; Erba et al. 1999; Hennig et al. 1999; van de Schootbrugge et al. 2000).

The positive carbon-isotope excursion in the late Valanginianearly Hauterivian was considered by Lini et al. (1992) to be a consequence of increased organic-carbon burial stimulated by increased productivity, much as proposed for excursions associated with Oceanic Anoxic Events (OAEs). They speculated that nutrient supply increased in the late Valanginian because of increased rates of continental weathering and runoff, stimulated by global warming caused by elevated atmospheric $p \mathrm{CO}_{2}$ levels. Although the Valanginian-Hauterivian is not generally thought of as a time of widespread deposition of organic carbon, sparse occurrences of black shales do occur at certain localities in the Tethyan and proto-Atlantic regions (Arthur \& Dean 1986; Stein et al. 1986, 1988; Summerhayes 1987; Lini et al. 1992; Sheridan et al. 1993), off East Antarctica (Barker et al. 1988), in the Arctic (Dypvik 1985; Hvoslef et al. 1986) and in the Pacific Basin (Bralower et al. 2002). Thus carbon burial may be an important feature in the origins of the Valanginian-Hauterivian carbon-isotope excursion.

\section{Geological setting and stratigraphy of the Wealden Beds, southern England}

The Lower Cretaceous Wealden Beds of southern England (Fig. 1) comprise variegated sandstones and mudstones interpreted as being of fluvial and lagoonal origin (Allen 1975, 1981; Stewart 1981). The Wealden Beds were deposited primarily in two areas: the Wessex and Weald basins (sensu Underhill \& Stoneley 1998), which were situated between various small massifs and may at times have had restricted connections with the Boreal Sea to the north (Allen 1975). The present study focused on Wessex Basin successions exposed on the Isle of Wight and in Dorset (Fig. 2), where long representative sections could be examined. On the Isle of Wight and at Swanage Bay in Dorset the predominantly fluvial channel sandstones and overbank mudstones of the Wessex Formation, of approximately Valanginian to mid-Barremian age, were succeeded by the lagoonal shales of the Vectis Formation, of approximately mid-Barremian to early Aptian age (Fig. 1; Allen \& Wimbledon 1991). Passing westward in Dorset, the Vectis Formation is apparently not present (Figs 1 and 2), possibly as a result of erosion before deposition of the

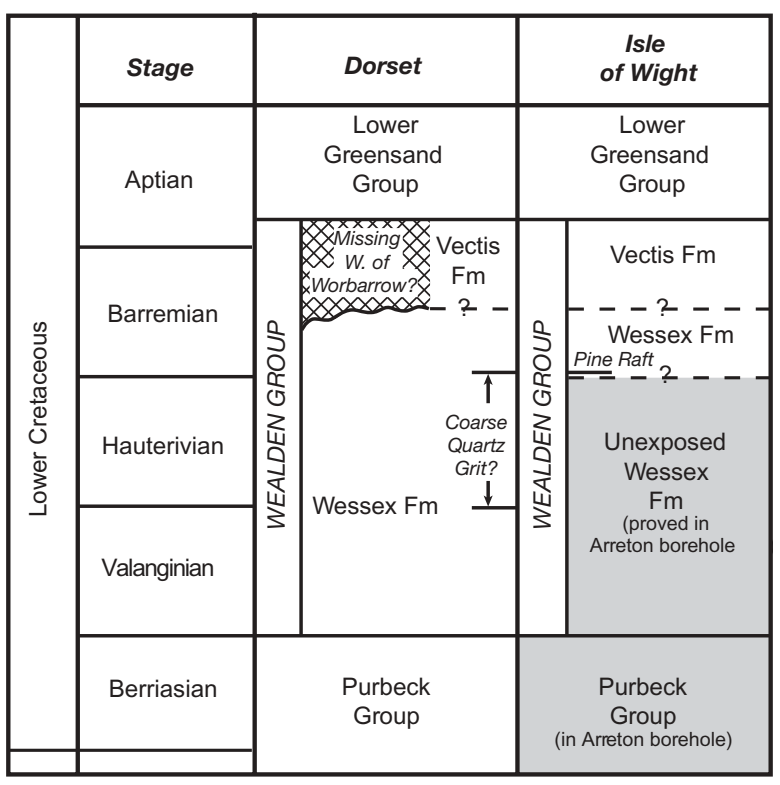

Fig. 1. Generalized lithostratigraphy for the onshore Wealden Group of southern England. After Allen \& Wimbledon (1991). The position of the Pine Raft and the range of possible positions of the Coarse Quartz Grit are shown. 

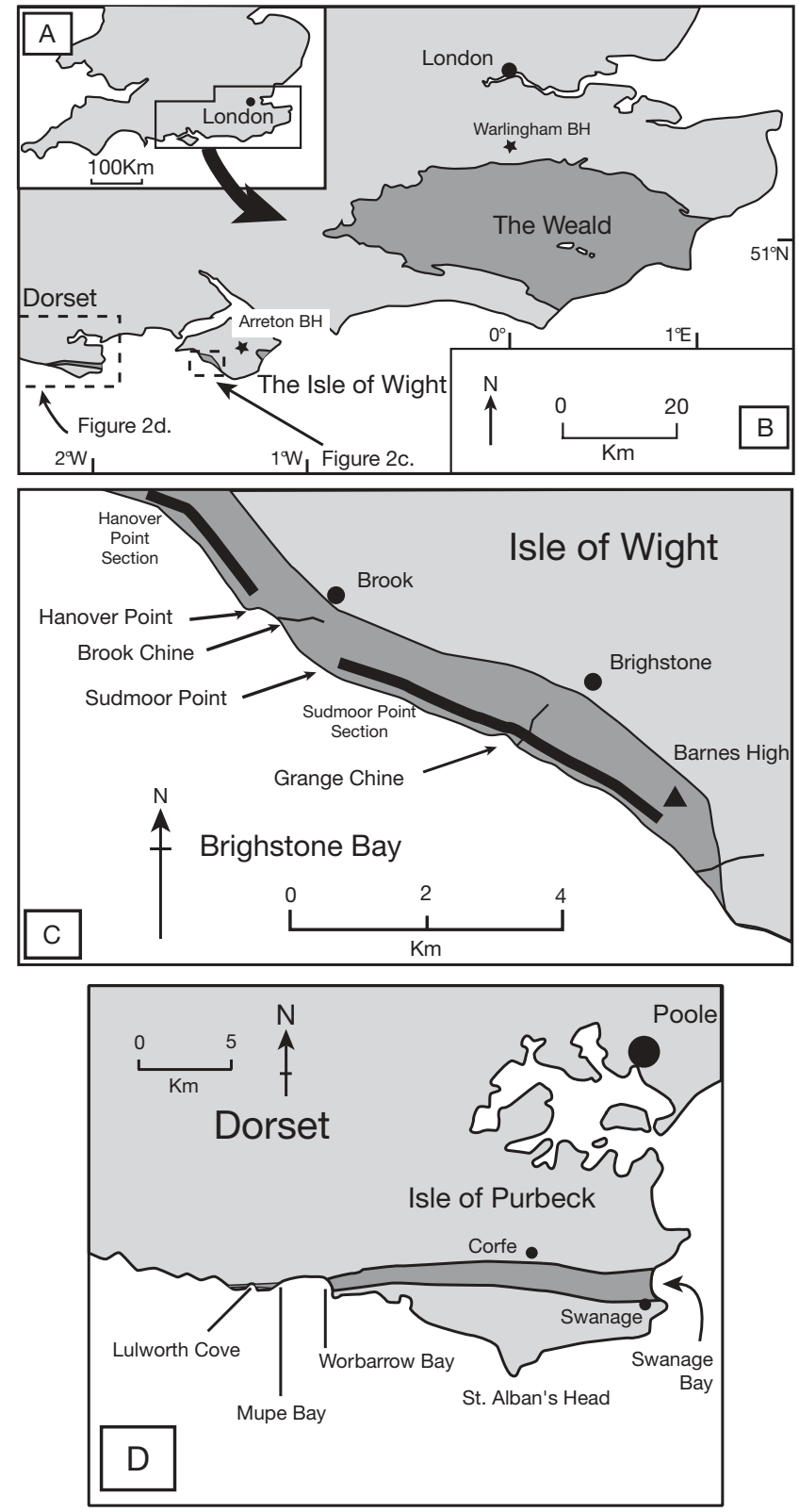

In figures B, C and D:

Wealden

(Lower Cretaceous)

Fig. 2. (a) Map of southern England and Wales. (b) Map showing the onshore outcrop of the Wealden Group (Lower Cretaceous) in southern England. The three main areas of outcrop (Dorset, the Isle of Wight and the Weald) are shown. This map also shows the locality of the Arreton and Warlingham boreholes (BH), which are discussed in the text. (c) Map of Brighstone Bay on the west coast of the Isle of Wight, showing localities discussed in the text (after Stewart 1981). The bold lines represent the two sections studied on the Isle of Wight. (d) Map of the Isle of Purbeck, Dorset, showing the position of localities discussed in the text.
Lower Greensand (Arkell 1947) or the general westward attenuation of the Lower Cretaceous sediments towards the Cornubian massif (Ruffell \& Batten 1994; Radley 1998). The close proximity of the Isle of Wight-Purbeck fault zone probably also had an effect on Wealden sedimentation in the Wessex Basin, as the downthrow on these faults decreases to the west. Within the Wessex Formation there are two beds of potential stratigraphic significance. First is the 'Coarse Quartz Grit', which can be mapped from Lulworth Cove to Swanage Bay (Arkell 1947) and is thought to represent an exceptionally high-velocity braided river system sourced from the Cornubian massif in the west (Allen 1998). Second, on the Isle of Wight, is a distinctive horizon at Hanover Point known as the 'Pine Raft', a bed that contains an abundance of charcoalified plant debris and may be the product of a local flash-flood debris flow (Insole \& Hutt 1994; Wright et al. 2000). Neither the Coarse Quartz Grit nor the Pine Raft are considered formal lithostratigraphic units within the Wessex Formation (see Allen \& Wimbledon 1991).

Because of their non-marine depositional setting, the Wealden sediments are not biostratigraphically constrained with a high degree of certainty. Attempts to establish a biozonation using palynomorphs for the Wealden Group of the Wessex Basin have been largely unsatisfactory because of the geographically and temporally restricted occurrences of taxa. Furthermore, correlation with marine sections has proved difficult as a result of the lack of intermediate facies (e.g. Harding 1986), although some early palynological work was the basis for correlation between non-marine strata in the Warlingham Borehole of the northern Weald Basin and marine sediments in eastern England (Hughes \& Moody-Stuart 1967; Hughes \& Croxton 1973).

The presence of diagnostic dinoflagellate cysts of both late Hauterivian and Barremian age in the Warlingham Borehole Wealden strata (Hughes \& Harding 1985; Harding 1986) provides some stratigraphic constraint for the position of the HauterivianBarremian boundary at this locality. Palynological correlations have subsequently been made from the Warlingham Borehole to other sections in the Wessex and Weald basins to allow a tentative application of stage boundaries at these localities (Hughes \& McDougall 1990). The exposed Wessex Formation on the Isle of Wight is Barremian in age according to palynological correlations with both the marine successions of eastern England and the Warlingham Borehole (Hughes 1958; Hughes \& McDougall 1990). According to these studies the Pine Raft occurs approximately at the Hauterivian-Barremian boundary. On the basis of palynology, Hughes \& Croxton (1973) considered the Coarse Quartz Grit in Worbarrow Bay to have been deposited at approximately the Valanginian-Hauterivian boundary. This was supported by correlation of leaf cuticle taxa by Oldham (1976). However, on the basis of further palynological work, Hughes \& McDougall (1990) revised these interpretations of the Coarse Quartz Grit, suggesting instead that it was deposited at the Hauterivian-Barremian boundary and was, thus, a proximal correlative of the Pine Raft. Nevertheless, sedimentological studies suggest that the processes governing the deposition of sandstones such as the Coarse Quartz Grit were radically different from those factors causing deposition of plant-debris beds such as the Pine Raft (see Insole \& Hutt 1994; Wright et al. 2000). This discordance casts considerable doubt on the revised palynological correlation suggested by Hughes \& McDougall (1990).

\section{Materials and methods}

Only in situ macroscopic fossil-wood samples (typically $>1 \mathrm{~cm}$ diameter) were collected for use in this study and their 
stratigraphic positions were carefully recorded. Features such as knots and branches can be recognized in some of the fossils despite being typically preserved as coal. The fossil wood was prepared for carbon-isotopic analysis by first washing and cleaning in deionized water. When necessary, fragmented samples were picked with tweezers from a sieve under a binocular light microscope. Samples were then air dried before being crushed into a fine powder and then $c .1 \mathrm{~cm}^{3}$ of each sample was placed in a $15 \mathrm{ml}$ centrifuge tube. To remove carbonate, fossil-wood samples were reacted with $10 \mathrm{ml}$ of $3 \mathrm{M}$ $\mathrm{HCl}$ for $1 \mathrm{~h}$. Hot $\mathrm{HCl}$ was used if pyrite was obviously present in the sample. The samples were then drained of $\mathrm{HCl}$ and the process was repeated. Samples were left overnight, rinsed with deionized water, centrifuged, drained and rinsed again until neutrality was reached, and then oven dried at $60^{\circ} \mathrm{C}$. Between 2.5 and $5 \mathrm{mg}$ of each sample was sealed in an $8 \mathrm{~mm} \times 6 \mathrm{~mm}$ tin capsule. These capsules were then placed in a Europa Scientific Limited CN biological sample converter connected to a 20-20 stable-isotope gas-ratio mass spectrometer. Carbonisotope ratios were measured against an internal standard and expressed as per mil (\%o) deviation from the Pee Dee belemnite (PDB).

\section{Carbon-isotope results from the Wessex Formation, southern England}

\section{Hanover Point, Isle of Wight}

At Hanover Point on the Isle of Wight (Fig. 2) the exposed Wessex Formation is c. $125 \mathrm{~m}$ thick (Fig. 3). Fossil wood is locally very abundant in this section. Carbon-isotope analyses of 22 fossil-wood fragments $\left(\delta^{13} \mathrm{C}_{\text {wood }}\right)$ have an average value of $-22.7 \%$. The range of carbon-isotope values $(-24.7 \%$ o to $-20.6 \%$ ) overlaps with the range typically expected for Mesozoic $\mathrm{C}_{3}$ plants ( $-23 \%$ o to $-27 \%$; Bocherens et al. 1993). When these results are viewed stratigraphically it is apparent that at the base of the succession there is an up-section increase in $\delta^{13} \mathrm{C}_{\mathrm{wood}}$ (between -120 and $-80 \mathrm{~m}$ depth in Fig. 3). Above this, carbonisotope data from fossil wood collected at about the level of the Compton Grange sandstone (c. $-30 \mathrm{~m}$ depth) are somewhat scattered.

\section{Sudmoor Point, Isle of Wight}

The section from Sudmoor Point to Barnes High exposes $c$. $180 \mathrm{~m}$ of the Wessex Formation, the base of which is possibly

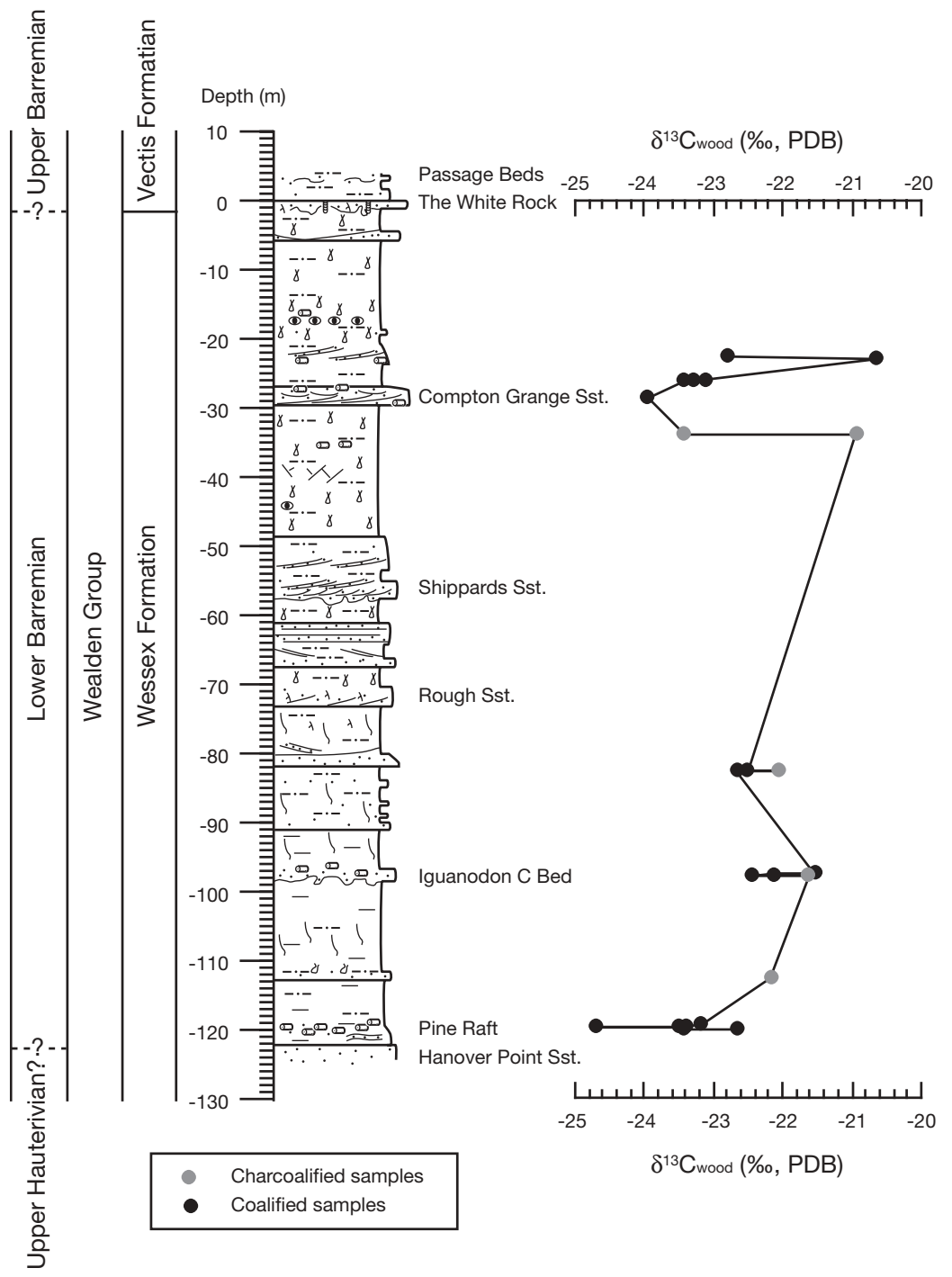

Fig. 3. Fossil-wood carbon-isotope stratigraphy of the Wessex Formation, between Hanover Point and Compton Chine (Compton Bay), Isle of Wight. Chronostratigraphy based upon Hughes \& McDougall (1990). 
late Hauterivian or early Barremian in age (Fig. 4). Carbonisotope values from this section have an average value of $-22.7 \%$, coincidentally identical to the average values for data from the Hanover Point section. As can be seen in Figure 4, there is a long-term trend up-section towards relatively more positive carbon-isotope values.

\section{Worbarrow Bay, Dorset}

Worbarrow Bay is an important Wealden Group locality because the relatively thick section represents most of the Wessex Formation. The principal gaps in the record are at the base of the section where c. $41 \mathrm{~m}$ are not exposed (Arkell 1947; this study) and at the top where the Vectis Formation is apparently not present, and some of the Wessex Formation may have been removed through erosion (Arkell 1947). Carbon-isotope analyses of fossil-wood fragments are shown in Figure 5 against our measured section. As with the data from the Isle of Wight sections, the fossil-wood carbon-isotope data from Worbarrow Bay are consistent with values expected for Mesozoic $\mathrm{C}_{3}$ plants. The data from Worbarrow Bay indicate an average carbonisotopic composition of $c$. $-23 \%$. As can be seen in Figure 5, there is a considerable amount of 'noise' in the carbon-isotope signal although no more than has been found in other comparable studies (e.g. Gröcke et al. 1999; Hesselbo et al. 2000, 2002, 2003). In the first $150 \mathrm{~m}$ we tentatively identify a broad positive excursion with a peak at $c .50 \mathrm{~m}$. Just above $150 \mathrm{~m}$ there is a single rather negative carbon-isotope data point, and it is notable

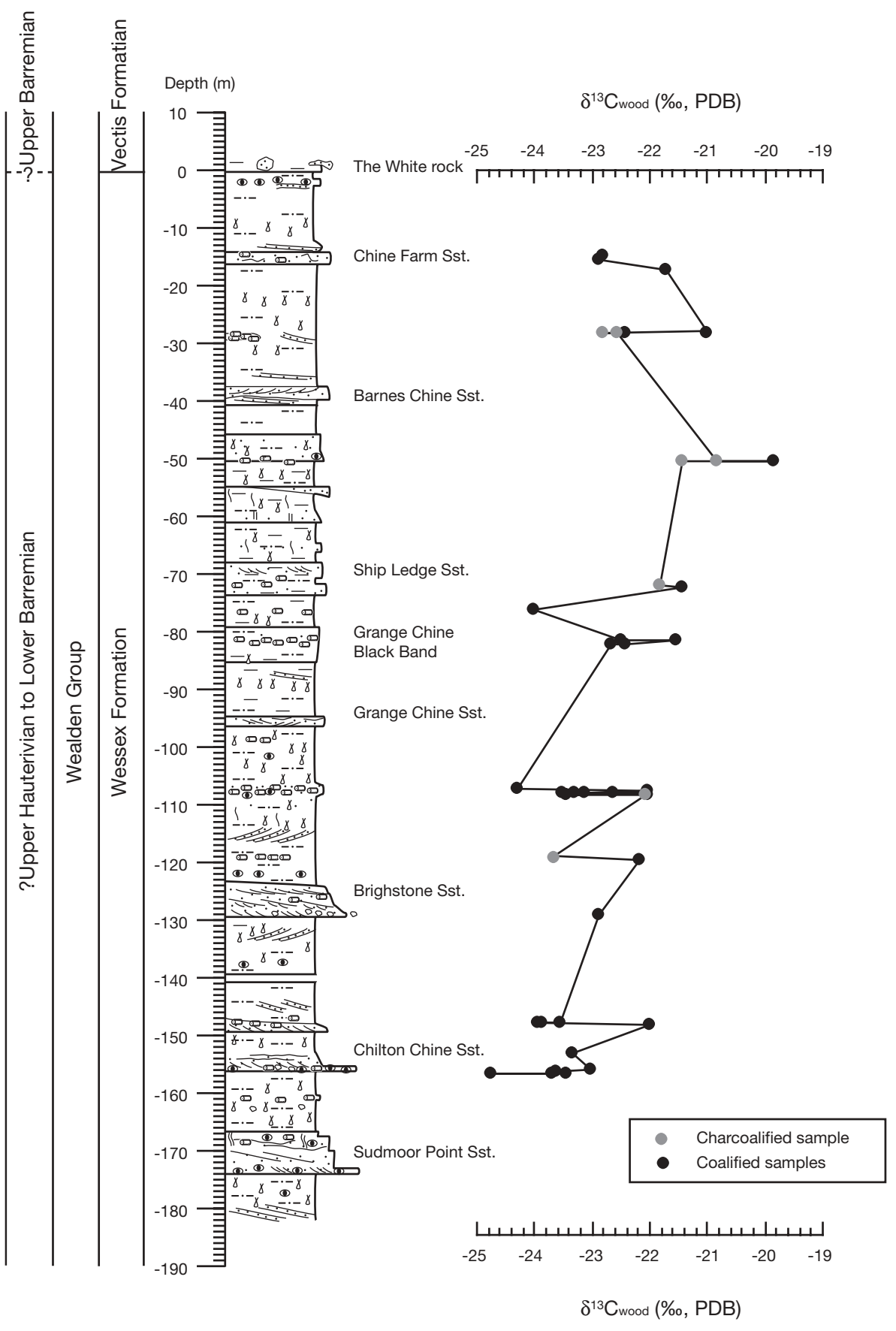

Fig. 4. Fossil-wood carbon-isotope stratigraphy for the Wessex Formation from Sudmoor Point to Barnes High (Brighstone Bay), Isle of Wight. Chronostratigraphy based upon Hughes \& McDougall (1990). 

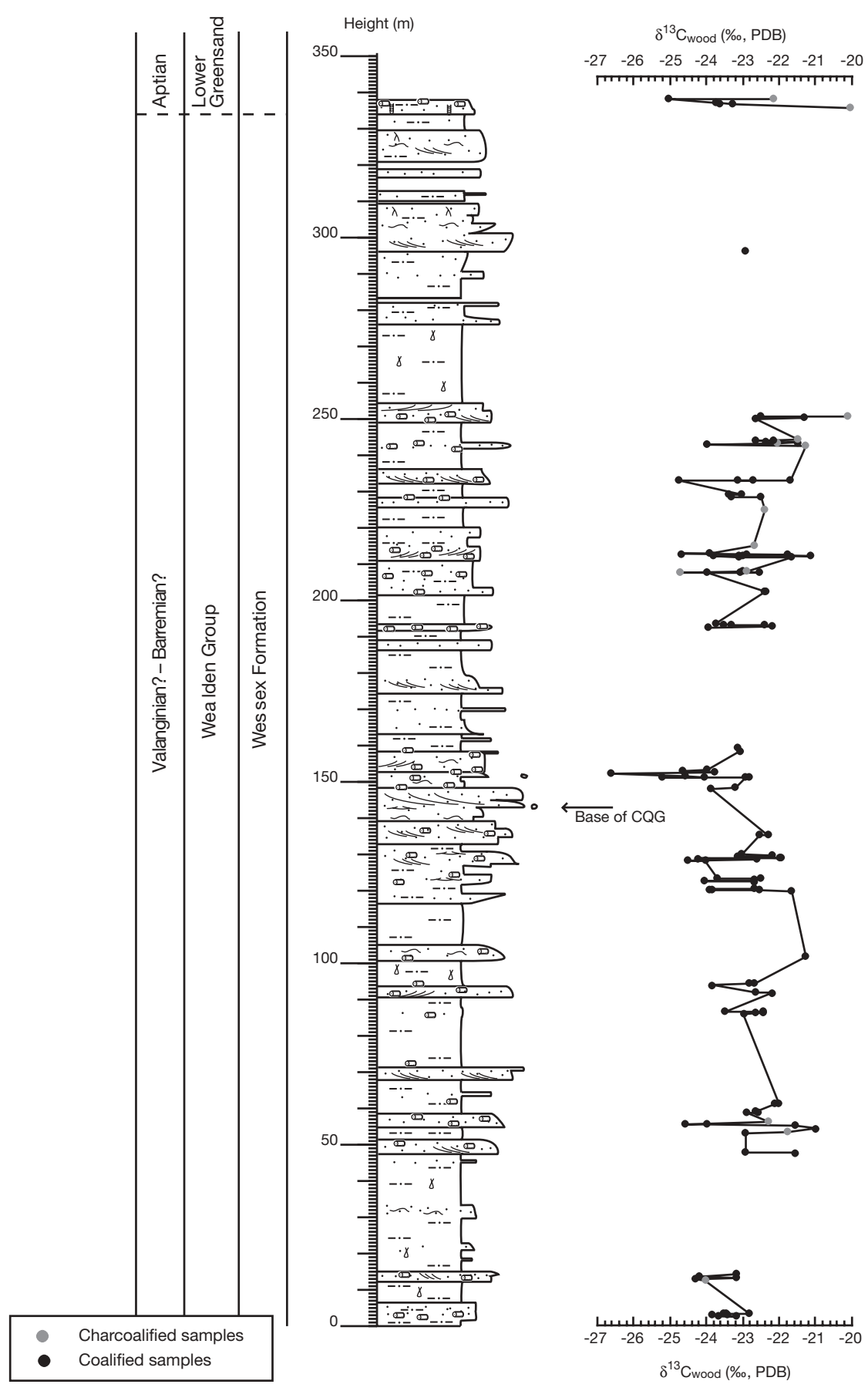

Fig. 5. Fossil-wood carbon-isotope stratigraphy from Worbarrow Bay, Dorset. CQG, Coarse Quartz Grit.

that other values at about this level are generally more negative than those from lower horizons. This tentative negative excursion exists over a narrow interval, with a return to pre-excursion values within $c .10 \mathrm{~m}$. Between $c .185$ and $250 \mathrm{~m}$ in Figure 5 there is an overall trend up-section to less negative $\delta^{13} \mathrm{C}_{\mathrm{wood}}$ values. A lack of fossil wood suitable for analysis between 250 and $340 \mathrm{~m}$ prevents investigation of carbon-isotopic trends over this interval. At the top of the section, fossil-wood carbonisotope data from the Lower Greensand Group (Aptian) have typical $\mathrm{C}_{3}$ plant values $(c .-23 \%$ ), with the exception of one point that is significantly more positive (c. $-20 \%$ ). However, the lack of data above and below these points prevents the confident detection of trends.

\section{Preservational and taxonomic concerns}

A potential source of the scatter seen in the carbon-isotopic data described above is variable preservation or sampling of more than one plant species. Previous studies have shown that there is little or no systematic difference between the carbon-isotopic composition of charcoalified and coalified fossil wood in various Mesozoic sections (e.g. Hesselbo et al. 2000, 2003; Gröcke 2001). Furthermore, the carbon-isotope data described here are almost entirely from coalified fossil-wood samples. Charcoalified samples make up approximately only $23 \%$ of the total samples at Hanover Point, $18 \%$ at Sudmoor Point and about $10 \%$ at Worbarrow Bay. Unfortunately, there is an insufficient number of samples of charcoal and coal from the same horizon to test 
whether there is significant variation in $\delta^{13} \mathrm{C}$ of differently preserved fossil wood at the same stratigraphic level.

It is well known that the carbon-isotopic composition of modern plants varies between species. Therefore, palaeo-studies should attempt to use a monospecific dataset through time. The Wessex Formation flora appears to have been dominated by a large conifer, Pseudofrenelopsis parceramosa (Watson \& Alvin 1996), which is also thought to have been the dominant source for most of the fossil wood (Alvin et al. 1981). P. parceramosa is a member of the extinct family of conifers called the Cheirolepidiaceae. The Cheirolepidiaceae have been associated with fairly extreme environments such as the hypersaline lagoons of the Purbeck Group (Cupressinocladus valdensis; Francis 1983). However, they were not entirely restricted to such environments as they have also been found associated with less extreme conditions in the Wealden of the Weald Basin (Batten 1974). The thickened cuticles, marginal hairs, reduced leaves and sunken stomata of $P$. parceramosa indicate that it was clearly adapted to tolerate highly water-stressed environments in a semi-arid climate. The adaptation to an extreme environment raises questions about whether Pseudofrenelopsis was using a normal $\mathrm{C}_{3}$ photosynthetic pathway or not. However, as mentioned above, the carbon-isotope data presented here are consistent with other studies of Mesozoic C 3 plants (Bocherens et al. 1993; Gröcke et al. 1999).

\section{Correlation of Wealden strata}

Correlations based on Wealden Group carbon-isotope datasets are limited in their accuracy and precision by a number of factors. First, the scatter present in the fossil-wood dataset limits identification of small-scale excursions. Second, the datasets are biased towards those horizons that contain fossil wood and typically gaps of $>5 \mathrm{~m}$ can be expected in the data series from the Wealden Group. These gaps are commonly associated with red beds in which any organic matter present at the time of deposition has been oxidized. Third, the lack of well-constrained conventional stratigraphic tie-points between the non-marine Wealden sediments and Tethyan carbonates makes it very difficult to evaluate independently correlations based on comparisons between the fossil-wood record and the marine signal. Finally, the highly variable and intermittent sedimentation of fluvial systems means that certain horizons may be strongly condensed or expanded relative to other horizons in the same section. Nevertheless, we believe that convincing first-order correlations are achievable.

\section{Intra- and inter-basinal correlations: the Isle of Wight sections}

The bias in sampling towards wood-rich horizons and the variable sedimentation rates at different localities makes it generally very hard to produce exact, 'bed-to-bed', intra-basinal correlations. On the other hand, patterns of isotopic change through thicker strata are shared by the different sections. Such a correlation is evident from the two Isle of Wight sections detailed in this study. Gröcke et al. (1999) published fossil-wood data from the Vectis Formation and Lower Greensand on the Isle of Wight. Their lowest samples occur at the White Rock, which marks the boundary between the Wessex and Vectis Formations. By plotting the data from Hanover Point and Sudmoor Point together with the data from Gröcke et al. (1999), it is possible to obtain a longer time-series of carbon-isotope data, and this allows us to see the Wessex Formation data in an improved stratigraphic context (Fig. 6). It thus becomes clear that the data from the sections at Hanover Point and Sudmoor Point are part of a broad trend towards less negative values that has a maximum between -50 and $+20 \mathrm{~m}$ in Figure 6 . This long-term positive excursion culminates in a sharp negative excursion at the base of the Lower Greensand. Overall the new data suggest that the long-term average sedimentation rates of the Wessex Formation at Hanover Point and Sudmoor Point are similar, despite potential small-scale variability.

The negative carbon-isotope excursion in the Lower Greensand and subsequent positive excursions are biostratigraphically and magnetostratigraphically constrained and have been correlated to carbon-isotope records from Tethyan carbonates (Gröcke et al. 1999). Therefore, the negative isotope excursion provides a reliable tie-point to the marine carbon-isotope record and aids correlation of the carbon-isotope data from the Vectis and Wessex Formations with the Tethyan record (Fig. 7). In Figure 7 it has been assumed that the sedimentation rates at Sudmoor Point and Hanover Point are identical and therefore the data from the two sections have simply been collated into height order. A three-point moving average has been applied to the compiled dataset in an attempt to remove some of the high-frequency scatter. Figure 7 shows that there are broad similarities between the data from the Wealden Group and data from the Barremian of the Cismon core, Italy, a suitable Tethyan reference section (Erba et al. 1999). However, it is not possible to determine the exact position of the Hauterivian-Barremian boundary or to be certain about correlations between small-scale fluctuations in the carbon-isotope records. The data also suggest that certain horizons may be condensed, such as the White Rock $(c .0 \mathrm{~m}$ in Fig. 6), where there is an atypical range in the carbon-isotope values. As noticed by Gröcke et al. (1999), some of the fluctuations in $\delta^{13} \mathrm{C}_{\text {wood }}$ have a much greater amplitude than those in $\delta^{13} \mathrm{C}_{\text {carbonate, }}$ which they attributed to changes in atmospheric $p \mathrm{CO}_{2}$. This means that the amplitude of a change in $\delta^{13} \mathrm{C}$ is an insufficient criterion to correlate between $\delta^{13} \mathrm{C}_{\text {wood }}$ and $\delta^{13} C_{\text {carbonate }}$ curves and that the character of the curve may be much more useful.

\section{A composite fossil-wood carbon-isotope curve for the Early Cretaceous}

A problem with the data from Worbarrow Bay, Dorset, is the uncertainty of the age range of the section (i.e. Hughes \& Croxton 1973; Oldham 1976; Hughes \& McDougall 1990), which makes it difficult to assign an independent stratigraphic tie-point from which to start chemostratigraphic correlation with the marine record. In the following analysis we have combined the Worbarrow Bay data with the Isle of Wight data to produce a composite fossil-wood carbon-isotope curve for the Early Cretaceous.

To produce this composite curve some assumptions have to be made. Of critical importance is the relative stratigraphic position of the Wessex Formation-Vectis Formation boundary on the Isle of Wight and at Worbarrow Bay. Ruffell \& Batten (1994) suggested that $7 \mathrm{~m}$ of shale at the very top of the Wessex Formation in Worbarrow Bay are a lateral equivalent of the Vectis Formation at Swanage. Strahan (1898, p. 127) noted that at Corfe railway station (between Swanage and Worbarrow) the Vectis loses 'its distinctive character as a shale, and ... [passes] ... westwards into sand and sandy clays'. However, further to the west (at Mupe Bay; Fig. 2) there may have been significant erosion of the Wessex Formation, before deposition of the Lower Greensand (Arkell 1947). Given the westward attenuation, 

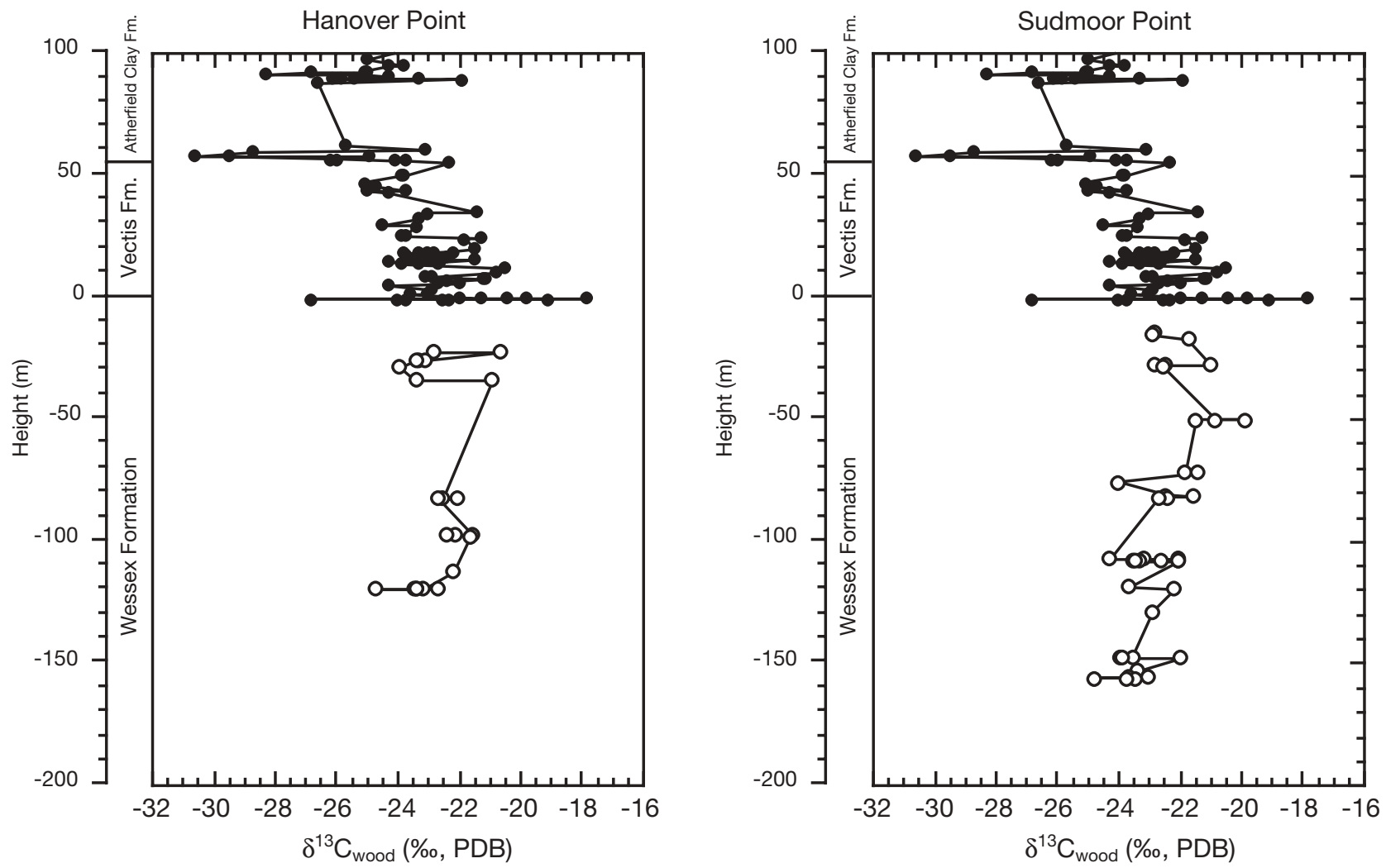

Fig. 6. Carbon-isotope stratigraphy for the Wealden Group (Wessex and Vectis Formations) and part of the Lower Greensand Group (Atherfield Clay Formation) on the Isle of Wight. $\odot$, data from the Wessex Formation. •, data from the Vectis Formation and the Atherfield Clay Formation, taken from Gröcke et al. (1999).

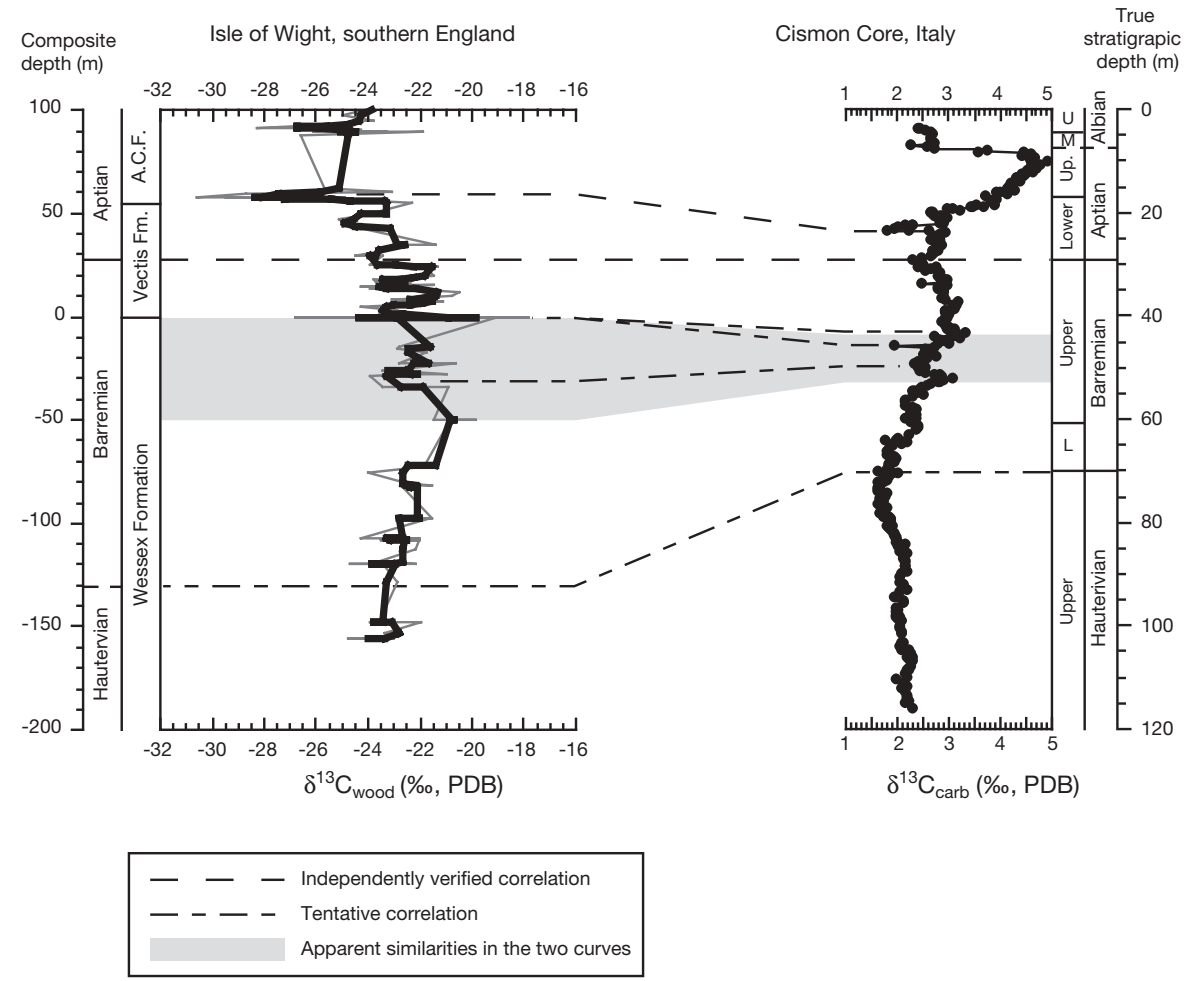

Fig. 7. Correlation between a smoothed, composite fossil-wood carbon-isotope curve from the Isle of Wight (data from this study and Gröcke et al. 1999) and the Cismon core, Italy (Erba et al. 1999). Independently verified correlation lines are based upon bio- and magnetostratigraphy (see Kerth \& Hailwood 1988; Gröcke et al. 1999).

Tentative correlations and the area shaded grey are based on similarities in the shape of the carbon-isotope data from the Isle of Wight and Cismon. A three-point moving average has been applied to the Isle of Wight data and is shown as the bold line. Raw data from the Isle of Wight are shown as a fine grey line. A.C.F., Atherfield Clay Formation 
possible erosion and lack of diagnostic fossils, it is impossible to say with any certainty that lateral equivalents of the Vectis Formation are definitely present at Worbarrow Bay. Our own observations at Worbarrow Bay show that there is a $4.5 \mathrm{~m}$ thick package of grey and green mudstone and fine sandstone below sediments that are clearly of the Lower Greensand. Whether these mudstones are equivalent to the Vectis Formation is not entirely clear. For the purposes of this composite curve it has been assumed that the Wealden Group-Lower Greensand boundary at Worbarrow Bay is age-equivalent to the top of the Wessex Formation on the Isle of Wight, and that the Vectis Formation, or lateral equivalents of it, are not present at Worbarrow Bay. If the following exercise is repeated with a thin $(<5 \mathrm{~m})$ Vectis Formation at Worbarrow Bay, the effect on the composite curve is negligible, given the other sources of uncertainty (i.e. field measurements; intra-formational erosion; assumption of equal sedimentation rates at Hanover Point and Sudmoor Point).

The thickness of the Wessex Formation in Worbarrow Bay is c. $376 \mathrm{~m}$ (including $41 \mathrm{~m}$ at the base which are not exposed), whereas in the Arreton Borehole on the Isle of Wight there is $c$. 557 m (Fig. 1; McLean 1953; Falcon \& Kent 1960). On the basis of seismic interpretations, the Wessex Formation on the west coast of the Isle of Wight has a total thickness similar to that in the Arreton Borehole (see Butler 1998). This suggests that the Wessex Formation in the Isle of Wight area is c. 1.5 times thicker than it is at Worbarrow Bay. To be able to plot all the data from Worbarrow Bay, Hanover Point and Sudmoor Point on the same composite depth scale, the Worbarrow Bay depth values have thus been scaled by a factor of $c$. 1.5. Figure 8 shows all

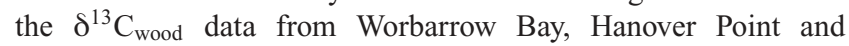
Sudmoor Point, and those of Gröcke et al. (1999), at their composite stratigraphic heights relative to the top of the Wessex Formation $(0 \mathrm{~m}$ is equivalent to the top of the Wessex Formation). In Figure 9 the complete composite fossil-wood dataset is shown along with a three-point running average. The results of the biostratigraphic work at Worbarrow Bay by Hughes \& Croxton (1973) and Hughes \& McDougall (1990) are shown, scaled to the composite depth scale. Figure 9 also shows a smoothed composite carbonate carbon-isotope curve for the Berriasian-Aptian from Tethyan sections (references in figure caption), which has been tentatively correlated with the fossilwood data, on the basis of similarities in the shape of the curves. The Barremian and Aptian have been correlated as they were in Figure 7. The tentative correlation between the Wealden composite isotope curve and the Tethyan carbon-isotope curve suggests that the Valanginian-Hauterivian boundary occurs below the Coarse Quartz Grit and that the Valanginian is relatively condensed in the English sections compared with the Hauterivian and Barremian.

\section{Implications}

\section{Fossil wood as a chemostratigraphic tool}

As mentioned above, long-term trends in the carbon-isotope values of fossil wood can be successfully used as a chemostratigraphic tool. An interesting feature of the data from the Wessex Formation is that the overall 'scatter-envelope' in carbon-isotopic values is similar to other comparable Mesozoic studies (Gröcke et al. 1999; Hesselbo et al. 2000, 2002, 2003). What is significant about the composite fossil-wood carbon-isotope curve presented here is that despite the change in facies from fluvial to lagoonal to shallow marine, there appears to be little effect on the degree of scatter or background fossil-wood carbon-isotope

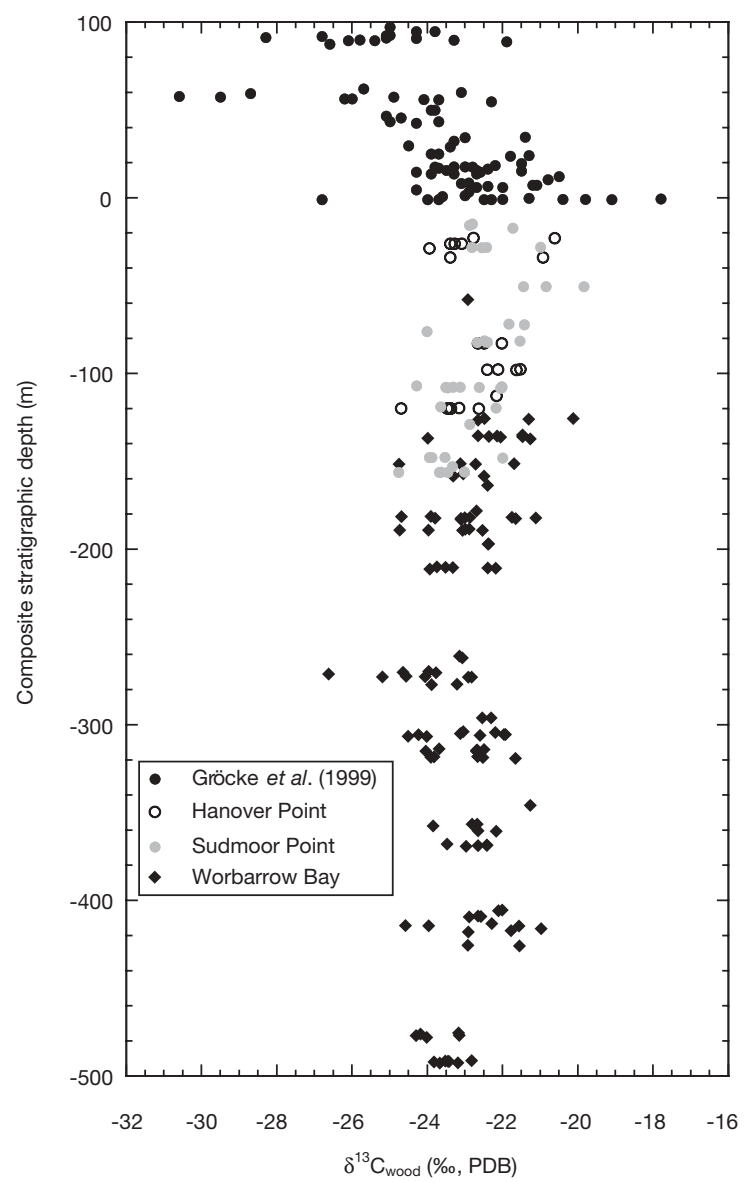

Fig. 8. Carbon-isotope data from Lower Cretaceous fossil wood collected from various locations and plotted on a composite depth scale. (See text for details.)

values (Fig. 8). This implies that major changes in facies (i.e. at the formation level rather than bed level) do not significantly affect the fossil-wood carbon-isotope record.

This study also highlights several other issues of importance regarding the use and limitations of fossil wood as a chemostratigraphic tool. The data from the Wessex Formation demonstrate that this technique is valid in fluvial sediments. However, local changes in sedimentation rate and the presence of sample gaps (as a result of severely oxidized horizons) can make interpretations difficult. To validate any correlations between a fossil-wood carbon-isotope curve and a marine reference carbonate curve, it is imperative that at least one point (but preferably more) in the fossil-wood stratigraphy can be independently correlated with the marine realm. This should be achieved by independent stratigraphic methods such as magnetostratigraphy or, where possible, marine biostratigraphy (as has been done in some previous studies; see Gröcke et al. 1999; Hesselbo et al. 2000, 2003).

\section{Wealden stratigraphy}

The fossil-wood carbon-isotope data and the inferred correlations presented here imply that the Wessex Formation is largely Hauterivian-Barremian in age. On the Isle of Wight, it is proposed that the Hauterivian-Barremian boundary should be 


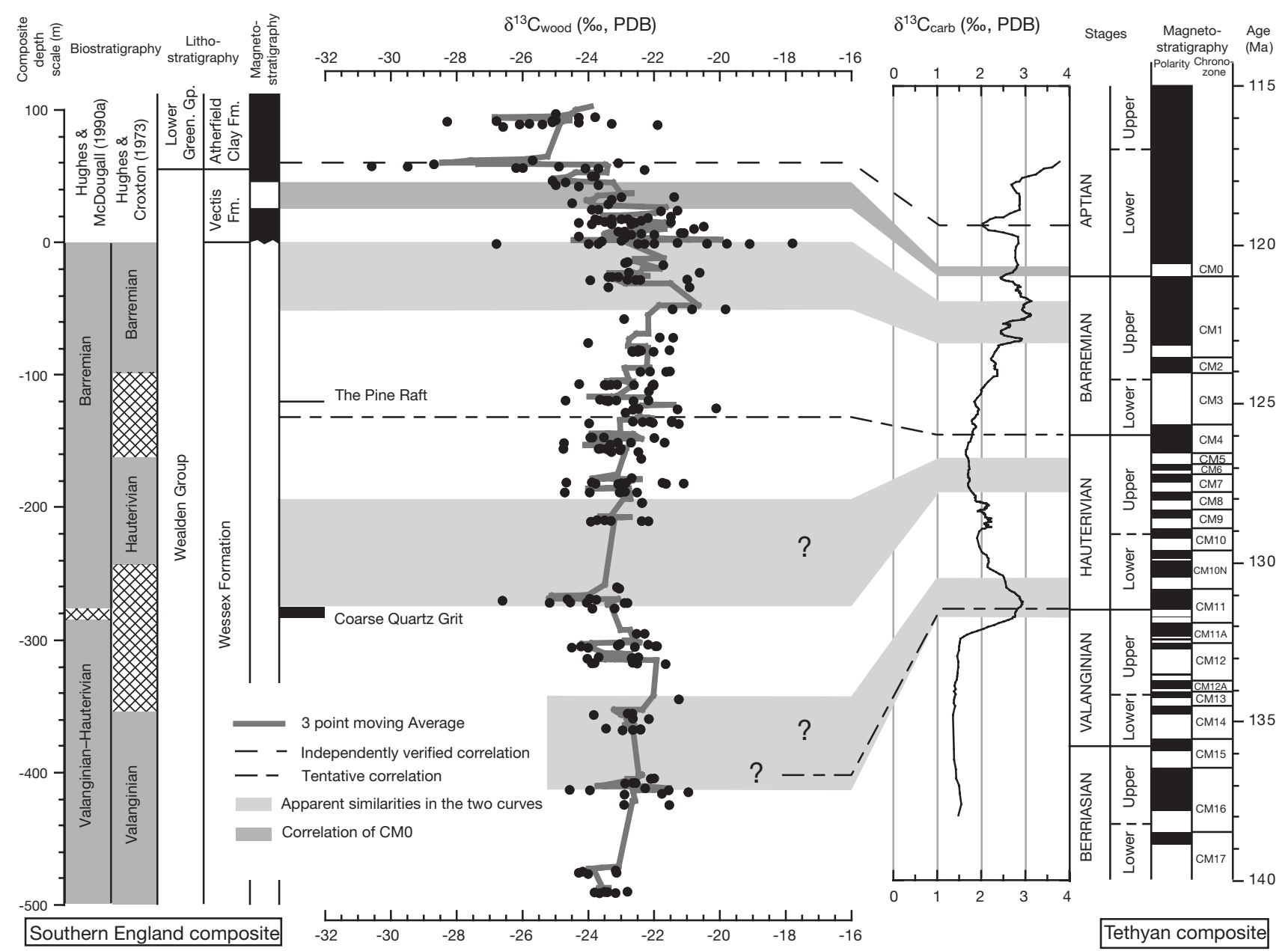

Fig. 9. Correlation between the composite fossil-wood carbon-isotope curve from southern England and a composite Tethyan carbonate carbon-isotope reference curve from various localities. Independent correlations based upon bio-, chemo- and magnetostratigraphy; tentative correlations based upon carbon-isotope stratigraphy. Southern England lithostratigraphy from Allen \& Wimbledon (1991); magnetostratigraphy from Kerth \& Hailwood (1988); carbon-isotope data from Gröcke et al. (1999) and this study. Tethyan carbon-isotope data from Capriola (Lini et al. 1992; Channell et al. 1993) and the Cismon APTICORE (Erba et al. 1999), both of which are in Italy. Time scale is from Channell et al. (1995) for all data below magnetochron CM0. Above CM0 (i.e. most of the Aptian) the time scale of Gradstein et al. (1995) has been used to assign the age of the lower-upper Aptian boundary. An agemodel was constructed for Capriola and Cismon by assigning ages to polarity chrons and thus points in the rock record. By assuming a constant sedimentation rate during each polarity chron it was possible to assign an age to each isotopic data point. To do this, magnetostratigraphic data fromChannell et al. (1987, 1993, 2000), Channell \& Erba (1992) and Erba et al. (1999) were used. Once an age point was assigned to each carbon-isotope data point, the entire carbon-isotope dataset was smoothed with a running three-point average. Lower Green. Gp., Lower Greensand Group.

placed close to the base of the exposed Wessex Formation, thereby supporting the long-held notion that the Pine Raft approximately marks this boundary (see Hughes 1958; Hughes \& McDougall 1990). However, the carbon-isotope data from Worbarrow Bay do not support the palynological correlation of the Coarse Quartz Grit with the Pine Raft on the Isle of Wight. Instead, it is proposed here that whereas the Pine Raft occurs at approximately the Hauterivian-Barremian boundary, the Coarse Quartz Grit is in fact older, probably mid-late Hauterivian. The carbon-isotope data also suggest that the Valanginian at Worbarrow Bay is relatively condensed compared with the Hauterivian. This is broadly in agreement with the palynological study of Hughes \& Croxton (1973). Interestingly, regional seismic and borehole studies of the Lower Cretaceous in the English Channel indicate the presence of unconformities in the basal Wealden sediments, especially towards the basin margins (Ruffell 1992; 1995). If these unconformities do exist then they could explain the apparent relative condensation of the Valanginian, as inferred from the carbon-isotope data.

\section{Early Cretaceous carbon cycling}

The ability to make geologically sound correlations between the data from the Isle of Wight and the Tethyan reference curve supports the hypothesis that the ocean-atmosphere carbon cycle was coupled during the Early Cretaceous, as previously demonstrated by several workers (i.e. Gröcke et al. 1999; Ando et al. 2002; Heimhofer et al. 2003). The trend towards more negative fossil-wood carbon-isotope values from the mid-Barremian (at the base of the Vectis Formation) onwards may be the result of increased outgassing of isotopically depleted volcanic $\mathrm{CO}_{2}$ driven by increased crustal production (Larson 1991; Larson \& Erba 1999) and coinciding with the beginning of local transgression, which may well be an expression of long-term eustatic sea- 
level rise. There is a hint of more positive fossil-wood carbonisotope values in the lower part of the Wealden at Worbarrow Bay (between -400 and $-300 \mathrm{~m}$ composite depth) that may be part of the late Valanginian-early Hauterivian positive carbonisotope excursion. If this were strengthened by further observations, then the Valanginian-Hauterivian event would indeed represent a global carbon-cycle perturbation.

An implication of the present work is that even during periods when the global carbon-cycle was relatively stable, the carbonisotopic composition of atmosphere $\mathrm{CO}_{2}$ faithfully tracked the long-term trends of the oceans. This result, in conjunction with independent estimates of atmospheric $p \mathrm{CO}_{2}$ (e.g. Robinson et al. 2002), is important for understanding the operation of the relatively steady-state carbon cycle during the HauterivianBarremian, before the massive perturbations of the mid-Cretaceous (Aptian-Turonian). This is significant for carbon-cycle modelling, as it suggests that the Tethyan carbonate-carbon isotope records are indeed representative of the entire exchangeable carbon reservoir. Some studies have suggested that it may be possible to use $\delta^{13} \mathrm{C}_{\text {plant }}$ to calculate the carbon-isotopic composition of palaeo-atmospheric $\mathrm{CO}_{2}\left(\delta^{13} \mathrm{C}_{\mathrm{atm}}\right.$; Arens et al. 2000; Gröcke 2002), an important variable for calculating $p \mathrm{CO}_{2}$ from the $\delta^{13} \mathrm{C}$ of soil carbonate (see Robinson et al. 2002 and references therein) and of importance to carbon-cycle models. However, there may be several problems inherent in the method of calculating $\delta^{13} \mathrm{C}_{\mathrm{atm}}$, in particular the effect of changing $p \mathrm{CO}_{2}$ on $\delta^{13} C_{\text {plant }}$ (see Beerling \& Royer 2002; Robinson 2002; Hesselbo et al. 2003). Until these issues are resolved, it will not be possible to calculate $\delta^{13} C_{\text {atm }}$ from $\delta^{13} C_{\text {plant }}$.

\section{Conclusions}

(1) Fossil wood samples from the non-marine Wessex Formation (Wealden Group, Lower Cretaceous, southern England) have carbon-isotope values in the range that is expected for Mesozoic $\mathrm{C}_{3}$ plants.

(2) Carbon-isotope data from the upper Wessex Formation sections on the Isle of Wight show progressively more positive values up-section. When these data are combined with previously published data from the overlying Vectis Formation it becomes apparent that there is a broad positive excursion in $\delta^{13} \mathrm{C}$ values, which peaks at about the Wessex Formation-Vectis Formation boundary. This broad excursion can be correlated with a similar excursion in the carbon-isotopic composition of Barremian Tethyan carbonates.

(3) Construction of a composite fossil-wood carbon-isotope curve for the Wealden Group allows some further tentative correlations to be made with marine Tethyan carbonates. These correlations suggest that the Wealden Group sediments are dominantly of Hauterivian and Barremian age and that the Valanginian is either condensed or partially missing.

(4) Lithological, sedimentological and chemostratigraphic evidence suggests that the Coarse Quartz Grit at Worbarrow Bay is not part of the same bed as the Pine Raft on the Isle of Wight. Furthermore, it is unlikely that any distal expression of the Coarse Quartz Grit is exposed on the Isle of Wight.

(5) The composite fossil-wood carbon-isotope curve from the Wessex Formation suggests that the Valanginian-Hauterivian positive carbon-isotope excursion may be present in the terrestrial carbon-isotope record. However, further work (both chemostratigraphic and magnetostratigraphic) is needed to verify this suggestion.

(6) The carbon-isotope signals recorded by the Tethyan marine carbonates are representative of the entire exchangeable carbon reservoir.

S.A.R. was funded by an NERC (UK) studentship (GT04/224/98/ES) whilst at Oxford. A. Gale, D. Gröcke and S. Showell are thanked for their assistance in the field. D. Batten, D. Gröcke, J. Hudson, H. Jenkyns and R. Spicer are thanked for useful discussion. E. Erba and A. Lini are gratefully acknowledged for supplying the raw data from the Tethyan sections. Carbon-isotope analyses were carried out at the Archaeological Research Laboratory at the University of Oxford; we gratefully acknowledge help from T. O'Connell, M. Humm and K. Neale. S. Wyatt is also thanked for his assistance in the laboratory. D. Batten and an anonymous reviewer are thanked for their constructive comments.

\section{References}

Allen, P. 1975. Wealden of the Weald: a new model. Proceedings of the Geologists' Association, 86, 389-437.

Allen, P. 1981. Pursuit of Wealden models. Journal of the Geological Society, London, 138, 375-405.

Allen, P. 1998. Purbeck-Wealden (early Cretaceous) climates. Proceedings of the Geologists' Association, 109, 197-236.

Allen, P. \& Wimbledon, W.A. 1991. Correlation of NW European PurbeckWealden (non-marine Lower Cretaceous) as seen from the English type-areas. Cretaceous Research, 12, 511-526.

Alvin, K.L., Fraser, C.J. \& SpICER, R.A. 1981. Anatomy and palaeoecology of Pseudofrenelopsis and associated conifers in the English Wealden. Palaeontology, 24, 759-778.

Ando, A., Kakegawa, T., Takashima, R. \& Saito, T. 2002. New perspective on Aptian carbon isotope stratigraphy: data from $\delta^{13} \mathrm{C}$ records of terrestrial organic matter. Geology, 30, 227-230.

Arens, N.C., Jahren, A.H. \& Amundson, R. 2000. Can $\mathrm{C}_{3}$ plants faithfully record the carbon isotopic composition of atmospheric carbon dioxide? Paleobiology, 26, 137-164.

Arkell, W.J. 1947. The Geology of the Country around Weymouth, Swanage, Corfe \& Lulworth. Memoirs of the Geological Survey of England and Wales, HMSO, London.

Arthur, M.A. \& DEAN, W.E. 1986. Cretaceous paleoceanography of the western North Atlantic Ocean. In: Tucholke, B.E. \& Dean, W.E. (eds) Decade of North American Geology, Western North Atlantic Basin Synthesis Volume. Geological Society of America, Boulder, CO, 617-630.

Barker, P.F. \& KennetT, J.P. ET AL. 1988. Sites 691 and 692. In: Barker, P.F. \& Kennett, J.P. (eds) Proceedings of the Ocean Drilling Program, Initial Reports, 113. Ocean Drilling Program, College Station, TX, 293-328.

Batten, D.J. 1974. Wealden palaeoecology from the distribution of plant fossils. Proceedings of the Geologists' Association, 85, 433-458.

Beerling, D.B. \& Royer, D.L. 2002. Fossil plants as indicators of the Phanerozoic global carbon cycle. Annual Review of Earth and Planetary Sciences, 30, 527-556.

Bender, M.M. 1971. Variations in the ${ }^{13} \mathrm{C} /{ }^{12} \mathrm{C}$ ratios of plants in relation to the pathway of photosynthetic carbon dioxide fixation. Phytochemistry, 10, 1239-1244.

Bocherens, H., Friss, E.M., Mariotti, A. \& Pedersen, K.R. 1993. Carbon isotopic abundances in Mesozoic and Cenozoic fossil plants, palaeoecological implications. Lethaia, 26, 347-358.

Bralower, T.J., CoBabe, E., Clement, B., Sliter, W.V., Osburn, C.L. \& Longoria, J. 1999. The record of global change in mid-Cretaceous (Barremian-Albian) sections from the Sierra Madre, northeastern Mexico. Journal of Foraminiferal Research, 29, 418-437.

Bralower, T.J., Premoli-Silva, I., Malone, M.J. et Al. (eds) 2002. Proceedings of the Ocean Drilling Program, Initial Reports, 198 (CD-ROM). Ocean Drilling Program, Texas A\&M University, College Station, TX.

Butler, M. 1998. The geological history of the Wessex Basin-a review of new information from oil exploration. In: Underhill, J.R. (ed.) Development, Evolution and Petroleum Geology of the Wessex Basin. Geological Society, London, Special Publications, 133, 67-86.

Cerling, T.E. \& Quade, J. 1993. Stable carbon and oxygen isotopes in soil carbonates. In: Swart, P.K., Lohmann, K.C., McKenzie, J.A. \& Savin, S. (eds) Climate Change in Continental Isotopic Records. Geophysical Monograph, American Geophysical Union, 78, 217-231.

Cerling, T.E., Wang, Y. \& Quade, J. 1993. Expansion of $\mathrm{C}_{4}$ ecosystems as an indicator of global ecological change in the late Miocene. Nature, 361, 344-345.

Channell, J.E.T. \& ERBA, E. 1992. Early Cretaceous polarity chrons CM0 to CM11 recorded in northern Italian land sections near Brescia. Earth and Planetary Science Letters, 108, 161-179. 
Channell, J.E.T., Bralower, T.J. \& Grandesso, P. 1987. Biostratigraphic correlation of Mesozoic polarity chrons CM1 to CM23 at Capriola and Xausa (Southern Alps, Italy). Earth and Planetary Science Letters, 85, 203-221.

Channell, J.E.T., Erba, E. \& Lini, A. 1993. Magnetostratigraphic calibration of the Late Valanginian carbon-isotope event in pelagic limestones from Northern Italy and Switzerland. Earth and Planetary Science Letters, 118, $145-166$.

Channell, J.E.T., Erba, E., Nakanishi, M. \& Tamaki, K. 1995. Late JurassicEarly Cretaceous time scales and oceanic magnetic anomaly block models. In: Berggren, W.A., Kent, D.V., Aubry, M.-P. \& Hardenbol, J. (eds) Geochrononology, Time Scales and Global Stratigraphic Correlation. Special Publication of the Society of Sedimentary Geology (SEPM), 54, 51-63.

Channell, J.E.T., Erba, E., Muttoni, G. \& Tremolada, F. 2000. Early Cretaceous magnetic stratigraphy in the APTICORE drill core and adjacent outcrop at Cismon (Southern Alps, Italy), and correlation to the proposed Barremian-Aptian boundary stratotype. Geological Society of America Bulletin, 112, 1430-1443.

Colombo, U., Gazzarrini, F., Gonfiantini, R., Kneuper, G., Teichmueller, M. \& Teichmuller, R. 1968. Das Verhaeltnis der stabilen KohlenstoffIsotope von Steinkohlen und kohlenbuertigem Methan in Nordwestdeutschland. Zeitschrift für Angewandte Geologie, 14, 257-265.

DypviK, H. 1985. Jurassic and Cretaceous black shales of the Janusfjellet Formation, Svalbard, Norway. Sedimentary Geology, 41, 235-248.

Erba, E., Channell, J.E.T. \& Claps, M. et AL. 1999. Integrated stratigraphy of the Cismon Apticore (southern Alps, Italy); a 'reference section' for the Barremian-Aptian interval at low latitudes. Journal of Foraminiferal Research, 29, 371-391.

Falcon, N.L. \& Kent, P.E. 1960. Geological Results of Petroleum Exploration in Britain 1945-1957. Geological Society, London, Memoirs, 2.

Föllmi, K.B., Weissert, H., Bisping, M. \& Funk, H. 1994. Phosphogenesis, carbon-isotope stratigraphy, and carbonate-platform evolution along the Lower Cretaceous northern Tethyan margin. Geological Society of America Bulletin, 106, 729-746.

Francis, J.E. 1983. The dominant conifer of the Jurassic Purbeck Formation, England. Palaeontology, 26, 277-294.

Gradstein, F.M., Agterberg, F.P., Ogg, J.G., Hardenbol, J., van Veen, P., Thierry, J. \& Huang, Z. 1995. A Triassic, Jurassic and Cretaceous time scale. In: Berggren, W.A., Kent, D.V., Aubry, M.-P. \& Hardenbol, J. (eds) Geochronology, Time Scales and Global Stratigraphic Correlation. Special Publication of the Society of Sedimentary Geology (SEPM), 54, 95-126.

GRöcKE, D.R. 1998. Carbon isotope analyses of fossil plants as a chemostratigraphic and palaeoenvironmental tool. Lethaia, 31, 1-13.

GRÖcKE, D.R. 2001. Isotope stratigraphy and ocean-atmosphere interactions in the Jurassic and Early Cretaceous. DPhil thesis, University of Oxford.

GRÖcKE, D.R. 2002. The carbon isotope composition of ancient $\mathrm{CO}_{2}$ based on higher-plant organic matter. Philosophical Transactions of the Royal Society of London, Series A, 360, 633-658.

Gröcke, D.R., Hesselbo, S.P. \& Jenkyns, H.C. 1999. Carbon-isotope composition of Lower Cretaceous fossil wood: ocean-atmosphere chemistry and relation to sea-level change. Geology, 27, 155-158.

Harding, I.C. 1986. An early Cretaceous dinocyst assemblage from the Wealden of southern England. Special Papers in Palaeontology, 35, 95-109.

Hasegawa, T. 1997. Cenomanian-Turonian carbon-isotope events recorded in terrestrial organic matter from northern Japan. Palaeogeography, Palaeoclimatology, Palaeoecology, 130, 251-273.

Heimhofer, U., Hochuli, P.A., Burla, S., Andersen, N. \& Weissert, H. 2003. Terrestrial carbon-isotope records from coastal deposits (Algarve, Portugal): a tool for chemostratigraphic correlation on an intrabasinal and global scale. Terra Nova, 15, 8-13.

Hennig, S., Weissert, H. \& Bulot, L. 1999. C-isotope stratigraphy, a calibration tool between ammonite- and magnetostratigraphy: the Valanginian-Hauterivian transition. Geologica Carpathica, 50, 91-96.

Hesselbo, S.P., Gröcke, D.R., Jenkyns, H.C., BJerrum, C.J., Farrimond, P.L., Morgans-Bell, H.S. \& Green, O.R. 2000. Massive dissociation of gas hydrates during a Jurassic Oceanic Anoxic Event. Nature, 406, 392-395.

Hesselbo, S.P., Robinson, S.A., Surlyk, F. \& Piasecki, S. 2002. Terrestrial and marine extinction at the Triassic-Jurassic boundary synchronized with major carbon-cycle perturbation: a link to initiation of massive volcanism? Geology, 30, 251-254

Hesselbo, S.P., Morgans-Bell, H.S., McElwain, J.C., Rees, P.M., Robinson, S.A. \& Ross, C.E. 2003. Carbon cycle perturbations in the Middle Jurassic and accompanying changes in the terrestrial paleoenvironment. Journal of Geology, 111, 259-276.

Hughes, N.F. 1958. Palaeontological evidence for the age of the English Wealden. Geological Magazine, 95, 41-49.

Hughes, N.F. \& Croxton, C.A. 1973. Palynologic correlation of the Dorset Wealden. Palaeontology, 16, 567-601.
HugheS, N.F. \& HARDING, I.C. 1985. Wealden occurrence of an isolated Barremian dinocyst facies. Palaeontology, 28, 555-565.

Hughes, N.F. \& McDougall, A.B. 1990. New Wealden correlation for the Wessex Basin. Proceedings of the Geologists' Association, 101, 85-90.

Hughes, N.F. \& Moody-Stuart, J.C. 1967. Palynological facies and correlation in the English Wealden. Review of Palaeobotany and Palynology, 1, 259-268.

Hvoslef, S., Dypvik, H. \& Solli, H. 1986. A combined sedimentological and organic geochemical study of the Jurassic/Cretaceous Janusfjellet Formation (Svalbard), Norway. Organic Geochemistry, 10, 101-111.

Insole, A.N. \& HUTT, S.P. 1994. The palaeoecology of the dinosaurs of the Wessex Formation (Wealden Group, Early Cretaceous), Isle of Wight, Southern England. Zoological Journal of the Linnean Society, 112, 197-215.

Jahren, A.H., Arens, N.C., Sarmiento, G., Guerrero, J. \& Amundson, R. 2001. Terrestrial record of methane hydrate dissociation in the Early Cretaceous. Geology, 29, 159-162.

Jenkyns, H.C. 1995. Carbon-isotope stratigraphy and paleoceanographic significance of the Lower Cretaceous shallow-water carbonates of Resolution Guyot, Mid-Pacific Mountains. In: Winterer, E.L., SAger, W.W. et al. (eds) Proceedings of the Ocean Drilling Program, Scientific Results, 143. Ocean Drilling Program, College Station, TX, 99-104.

Jenkyns, H.C. \& Wilson, P.A. 1999. Stratigraphy, paleoceanography, and evolution of Cretaceous Pacific guyots: relics from a greenhouse Earth. American Journal of Science, 299, 341-392.

Jones, T.P. \& Chaloner, W.G. 1991. Fossil charcoal, its recognition and palaeoatmospheric significance. Global and Planetary Change, 5, 39-50.

KeRTH, M. \& HaiLwood, E.A. 1988. Magnetostratigraphy of the Lower Cretaceous Vectis Formation (Wealden Group) on the Isle of Wight, southern England. Journal of the Geological Society, London, 145, 351-360.

Kuypers, M.M.M., Pancost, R.D. \& Sinninghe Damsté, J.S. 1999. A large and abrupt fall in atmospheric $\mathrm{CO}_{2}$ concentration during Cretaceous times. Nature, 399, 342-345.

LARSON, R.L. 1991. Geological consequences of superplumes. Geology, 19, 963-966.

LARson, R.L. \& ERBA, E. 1999. Onset of the mid-Cretaceous greenhouse in the Barremian-Aptian: igneous events and the biological, sedimentary, and geochemical responses. Paleoceanography, 14, 663-678.

LeavitT, S.W. \& Long, A. 1982. Evidence for ${ }^{13} \mathrm{C} /{ }^{12} \mathrm{C}$ fractionation between tree leaves and wood. Nature, 298, 742-744.

LeavitT, S.W. \& Long, A. 1986. Stable carbon isotope variability in tree foliage and wood. Ecology, 67, 1002-1010.

LeavitT, S.W. \& Long, A. 1991. Seasonal stable-carbon isotope variability in tree rings: possible palaeoenvironmental signals. Chemical Geology (Isotope Geoscience Section), 87, 59-70.

Lini, A., Weissert, H. \& Erba, E. 1992. The Valanginian carbon isotope event: a first episode of greenhouse climate conditions during the Cretaceous. Terra Nova, 4, 374-384.

Loader, N.J., Switsur, V.R. \& Field, E.M. 1995. High-resolution stable isotope analysis of tree rings: implications of 'microdendroclimatology' for palaeoenvironmental research. The Holocene, 5, 457-460.

Luciani, V., Cobianchi, M. \& Jenkyns, H.C. 2001. Biotic and geochemical response to anoxic events; the Aptian pelagic succession of the Gargano Promontory (southern Italy). Geological Magazine, 138, 277-298.

McLean, R.G. 1953. Geological completion report of Arreton No. 1 Well, Isle of Wight. Supplemented by P. E. Kent. Unpublished report for D'Arcy Exploration Company Limited.

Menegatti, A.P., Weissert, H., Brown, R.S., Tyson, R.V., Farrimond, P., Strasser, A. \& Caron, M. 1998. High-resolution $\delta^{13} \mathrm{C}$ stratigraphy through the early Aptian 'Livello Selli' of the Alpine Tethys. Paleoceanography, 13, $530-545$.

Michalíx, J., Reháková, D., Hladíková, J. \& Lintnerová, O. 1995. Lithological and biological indicators of orbital changes in Tithonian and Lower Cretaceous sequences, Western Carpathians, Slovakia. Geologica Carpathica, 46, 161-174.

Oldham, T.C.B. 1976. Flora of the Wealden plant debris beds of England. Palaeontology, 19, 437-502.

RADLEY, J.D. 1998. 'Structures affecting the coast around Lulworth Cove, Dorset and syn-sedimentary Wealden faulting' by Nowell (1997): comment. Proceedings of the Geologists' Association, 109, 237-240.

Robinson, S.A. 2002. Carbon cycling, palaeoatmospheres and isotope stratigraphy of marginal and non-marine Mesozoic sediments. DPhil thesis, University of Oxford.

Robinson, S.A., Andrews, J.E., Hesselbo, S.P., Radley, J.D., Dennis, P.F., Harding, I.C. \& Allen, P. 2002. Atmospheric $p \mathrm{CO}_{2}$ and depositional environment from stable-isotope geochemistry of calcrete nodules (Barremian, Lower Cretaceous, Wealden Beds, England). Journal of the Geological Society, London, 159, 215-224.

Ruffell, A.H. 1992. Early to mid-Cretaceous tectonics and unconformities of the Wessex Basin (southern England). Journal of the Geological Society, London, 149, 443-454. 
Ruffell, A.H. 1995. Seismic stratigraphic analysis of non-marine Lower Cretaceous strata in the Wessex and North Celtic Sea Basin. Cretaceous Research, 16, 603-637.

Ruffell, A.H. \& Batten, D.J. 1994. Uppermost Wealden facies and Lower Greensand Group (Lower Cretaceous) in Dorset, southern England: correlation and palaeoenvironment. Proceedings of the Geologists' Association, 105, 53-69.

SCHLESER, G.H. $1999 .{ }^{13} \mathrm{C} /{ }^{12} \mathrm{C}$ in growth rings and leaves: carbon distribution in trees. In: Jones, T.P. \& Rowe, N.P. (eds) Fossil Plants and Spores: Modern Techniques. Geological Society, London, 306-309.

Scholle, P.A. \& ARTHur, M.A. 1980. Carbon isotope fluctuations in Cretaceous pelagic limestones: potential stratigraphic and petroleum exploration tool. AAPG Bulletin, 64, 67-87.

Sheridan, R.E. \& Gradstein, F.M. ET AL. 1993. Site 534: Blake-Bahama Basin. In: Sheridan, R.E., Gradstein, F.M. ET AL. (eds) Initial Reports of the Deep Sea Drilling Project, 76. US Government Printing Office, Washington, DC, 76, 141-340.

Smith, B.N. \& Epstein, S. 1971. Two categories of ${ }^{13} \mathrm{C} /{ }^{12} \mathrm{C}$ ratios for higher plants. Plant Physiology, 47, 380-384.

SPICER, R.A. 1989. Physiological characteristics of land plants in relation to environment through time. Transactions of the Royal Society of Edinburgh: Earth Sciences, 80, 321-329.

Spiker, E.C. \& Hatcher, P.G. 1987. The effects of early diagenesis on the chemical and stable carbon isotopic composition of wood. Geochimica et Cosmochimica Acta, 51, 1385-1391.

Stein, R., Rullkötter, J. \& Welte, R. 1986. Accumulation of organic-carbonrich sediments in the late Jurassic and Cretaceous Atlantic Ocean-a synthesis. Chemical Geology, 56, 1-32.

Stein, R., Rullkötter, J., Littke, R. \& Schaefer, R.G. et al. 1988. Organofacies reconstruction and lipid geochemistry of sediments from the Galicia Margin, Northeast Atlantic (ODP Leg 103). In: BoIllot, G. \& Winterer, E.L. (eds) Proceedings of the ODP, Scientific Results, 103. Ocean Drilling Program, College Station, TX, 567-585.

Stewart, D.J. 1981. A field guide to the Wealden Group of the Hastings area and the Isle of Wight. In: Elliot, T. (ed.) Field Guides to Modern and Ancient Fluvial Systems in Britain and Spain. International Fluvial Conference, University of Keele, 3.1-3.32.
Strahan, A. 1898. The Geology of the Isle of Purbeck and Weymouth. Memoirs of the Geological Survey of England and Wales, HMSO, London.

Summerhayes, C.P. 1987. Organic-rich sediments from the North Atlantic. In: Brooks, J. \& Fleet, A. (eds) Marine and Petroleum Source Rocks. Geological Society, London, Special Publications, 26, 301-316.

Throughton, J.H., Wells, P.V. \& Mooney, H.A. 1974. Photosynthetic mechanisms in ancient $\mathrm{C}_{4}$ and CAM species. Carnegie Institution of Washington Yearbook, 73, 698-701.

UNDERHill, J.R. \& STONELEY, R. 1998. Introduction to the development, evolution and petroleum geology of the Wessex Basin. In: UNDERHILL, J.R. (ed.) Development, Evolution and Petroleum Geology of the Wessex Basin. Geological Society, London, Special Publications, 133, 1-18.

van De Schootbrugge, B., Föllmi, K.B., Bulot, L.G. \& Burns, S.J. 2000. Paleoceanographic changes during the early Cretaceous (Valanginian-Hauterivian): evidence from oxygen and carbon stable isotopes. Earth and Planetary Science Letters, 181, 15-31.

VOGEL, J.C. 1993. Variability of carbon isotope fractionation during photosynthesis. In: Ehleringer, J.R., Hall, A.E. \& Farquhar, G.D. (eds) Stable Isotopes and Plant Carbon-Water Relations. Academic Press, New York, 29-46.

Watson, J. \& Alvin, K.L. 1996. An English Wealden floral list, with comments on possible environmental indicators. Cretaceous Research, 17, 5-26.

WEISSERT, H. \& BRÉHÉRET, J.-G. 1991. A carbonate carbon-isotope record from Aptian-Albian sediments of the Vocontian trough (SE France). Bulletin de la Société Géologique de France, 162, 1133-1140.

Weissert, H., Lini, A., Föllmi, K.B. \& Kuhn, O. 1998. Correlation of Early Cretaceous carbon-isotope stratigraphy and platform drowning events: a possible link? Palaeogeography, Palaeoclimatology, Palaeoecology, 137, 189-203.

Wortmann, U.G. \& Weissert, H. 2000. Tying platform drowning to perturbations of the global carbon cycle with a $\delta^{13} \mathrm{C}_{\text {org }}$ curve from the Valanginian of DSDP Site 416. Terra Nova, 12, 289-294.

Wright, V.P. \& VANSTONE, S.D. 1991. Assessing the carbon dioxide content of ancient atmospheres using palaeo-calcretes: theoretical and empirical constraints. Journal of the Geological Society, London, 148, 945-947.

Wright, V.P., TAYlor, K.G. \& Beck, V.H. 2000. The paleohydrology of Lower Cretaceous seasonal wetlands, Isle of Wight, southern England. Journal of Sedimentary Research, 70, 619-632.

Received 10 January 2003; revised typescript accepted 30 July 2003.

Scientific editing by Jane Francis 